International Journal of Instruction e-ISSN: 1308-1470 • www.e-iji.net
July $2018 \bullet$ Vol.11, No.3

p-ISSN: 1694-609X

pp. 391-402

Received: 13/10/2017

Revision: 30/03/2018

Accepted: 04/04/2018

\title{
Investigating Factors Influencing Mathematics Teaching Performance: An Empirical Study
}

\section{Pardimin}

Sarjanawiyata Tamansiswa University, Indonesia

\section{Miftachul Huda}

Corresponding author, Universiti Teknologi Malaysia, Malaysia, halimelhuda@gmail.com

This study aims to explore the factors influencing teaching performance in mathematics. With the sample 306 mathematics teachers in Yogyakarta region, Indonesia selected by the balanced random sampling technique, the data collection was employed done using the Likert Scale questionnaire instrument with validity and reliability. The finding of this study would be viewed from the theoretical and practical perspectives in which theoretically it supports the Indonesian government regulation in providing teaching services within educational system. The result revealed there are five core potentials in assisting the teaching performance. Those are knowledge, attitude, skills, beliefs of mathematics and certification. It can be reflected by the lesson planning construct, learning procedure and the connection between personalities in the sense that constructs the relation to other subjects, education and curriculum, and teaching and education. Towards pedagogical, professional, personal and social skills, this initiative refers to strengthen the beliefs construct among knowledge, education and self-confidence in assisting the teaching performance.

Keywords: structural model, teaching performance, mathematics, teaching, learning

\section{INTRODUCTION}

The challenge of teaching performance is crucial which needs to solve in the academic basis. One of the efforts of the Indonesian government to tackle this issue can be seen from announcing the service program to assist the quality teaching within the law regulation (Ministry of Education, 2005). This initiative is supposed to enhance the quality with strengthening the academic qualification, including skills, teaching performance and capacity in facing the teaching issues. Based on the statistics, Indonesia reached to the level 35 from 46 nations in the educational mastery of mathematics. Moreover, the ranking of Indonesia places at 411 where it is followed by Singapore (605) and Malaysia (508). In 2007, Indonesia achieves to raise the ranking into the level 36 with the score 397 while Singapore and Malaysia were at 593 and 474 respectively (Ministry of Education, 2011).

Citation: Pardimin, \& Huda, M. (2018). Investigating Factors Influencing Mathematics Teaching Performance: An Empirical Study. International Journal of Instruction, 11(3), 391-402. https://doi.org/10.12973/iji.2018.11327a 
According to the information from Education Quality Assurance in Jogjakarta, Indonesia, there is needed to improve the work performance quality among the teachers, since the evaluation quotient of teachers' work performance shows less than 50 percent, with the following result Yogyakarta (42.86\%), Sleman (38.46\%), Bantul (37.50\%), Kulon Progo $(25 \%)$ and Gunung Kidul (16.67\%). Moreover, the challenge is additionally emerged from the students' learning performance and achievement which shows less than an expected result. One of the reasons can be seen from the lack of competitiveness among the students in the rural area in is Yogyakarta, Indonesia. The indicators could be viewed such as less attention to the mathematics education, getting hard to operate the formulation, and sometimes cheating from their peers and soon, where all these have to be solved mainly in the teaching performance in mathematics (Othman et al., 2016). In particular, the learning strategy adopted is sometimes using traditional method and thus the students are unfamiliar with problem-solving or using ubiquitous applications (Zulkardi 2002).

In this view, this study aims to explore the model development of what kind of factors can influence mathematics teachers' work performance. This study will propose the analytical model referring to the relationship among knowledge, belief and attitude in the work teaching performance (Ernest, 1989; Shulman, 1986). This study will focus on five factors which are considered to be more dominant in influencing mathematics teachers' work performance in Yogyakarta, Indonesia. These include teachers' knowledge, attitude, skills, beliefs in mathematics and certification. They will be analysed to determine the extent of influence on mathematics teachers' work performance.

\section{LITERATURE REVIEW}

\section{About Teaching Performance}

Teachers' work performance is the result and development which are achieved by the teacher in performing assigned duties and responsibilities based on factors of ability, presentation or skills, family background, social status, experience, age, gender, ethnicity, academic qualifications, work experience, resources, leadership, reward, structure and nature of work, perception, attitude, personality, learning, and motivation (Shulman, 1987). Attempt to value the teaching performance refers to the appraisal with its particular stages used to identify the basic needs with a key indicator to support the abilities and capabilities in teaching. Examining the strength and weakness, the evaluation process involves five main aspects namely, the purpose of evaluation, category of targeted teachers to be evaluated, concept of teachers' work used, attention to the teachers' quality dimension and behaviour, and approach to validate the evaluation (Huda et al., 2016a; Lim-Teo et al., 2008). Moreover, there are some additional stages which are intelligence, personality, teaching techniques and interaction with students (Huda et al., 2016b). It can also be examined into the skills in teaching, motivating ability, sincerity in passing, and teachers' attitude towards students (Riaz, 2000). In addition, teaching work performance in the school system would be assessed using instruments designed in the duration of the learning process integrated into the purpose and activities of the educational institution. The most important indicator for teachers' work performance is the activity opted by the teacher when teaching a subject (Klassen \& Tze, 2014). The role of students and the school management becomes the instruments which are crucial in teacher evaluation. 


\section{The Significance of Knowledge, Attitude, Skill, Belief and Certification on Teaching Performance}

Teaching performance could be improved with addressing knowledge, attitude, skill, belief and certification. All these have their significant role to enhance the teaching performance. With their relationship, it can support the way of teaching style by managing the process in the sense that focuses on determining the factors in influencing the teaching performance. Some studies have been explored in terms of the significance on these components (Wilkins, 2008; Agudelo-Valderrama, 2008; Lim-Teo, et al., 2008; Henderson \& Susan , 2008; Huntly, 2008; Capraro et al., 2005; Charalambous et al., 2009; Xu, 2004; Fiedler, 2009). These components have been considered with a comprehensive structural model of teaching performance. Formulating the model components were adopted into the mathematical content knowledge to enlarge the professional quality of teaching performance.

In addition, the significance of knowledge and skills to enhance the teaching quality can be engaged into the service programs. The certification program is provided to signify their key performance in teaching. In providing the idea to improve work performance, the development of an effective education program refers to assist the students' learning performance (Toh et al. 2003). As a result, the use of learning materials including illustrations and examples points out the teaching to give insights into the learning process of mathematics in a classroom (Suffian, \& AbdulRahman, 2010). Both knowledge understanding with belief and attitude have a pivotal overview to address the foundational thinking in raising the professionalism which is crucial in creating effective mathematics teaching (Koellner Clark, \& Lesh, 2003).

In line with teaching performance including knowledge on teaching methods, attitude and students' success, the self-confidence which is directly nurtured by teachers positively influences work quality and acquisition purposes of students with their learning expertise (Maseleno et al., 2018), work results and approach used by teachers and mathematics performance (Munck, 2007). Here refers to the self-confidence in giving the particular view into the direct effect on learning purpose with effective approaches. As a result, the value has a direct positive effect on mathematics performance with an approach that attitude, anxiety and habit as affective ability in the learning of mathematics act as a spur to continue in encouraging cognitive abilities to stimulate learners to solve mathematical problems (Huda et al., 2017). Effective mathematics problem solving enables learners to obtain high mathematical achievement in the sense that both commitment and interest with the general understanding can be integrated with understanding and mastering content, which have a positive relationship with teaching performance.

\section{METHOD}

The present study was designed with quantitative approach using an ex post facto (Isaac \& Michael, 1981). This quasi-experimental study was used to examine independent variable, present prior to the study in the participants, affects a dependent variable where the participants are not randomly assigned. In the ex post facto study, relation among variables is significantly related and factors influenced are interesting to research (Christensen, 2004). With this regard, the factors to influence mathematics teachers' work performance will be examined among knowledge, attitude, beliefs and certification in mathematics education as in the following figure 1 . 


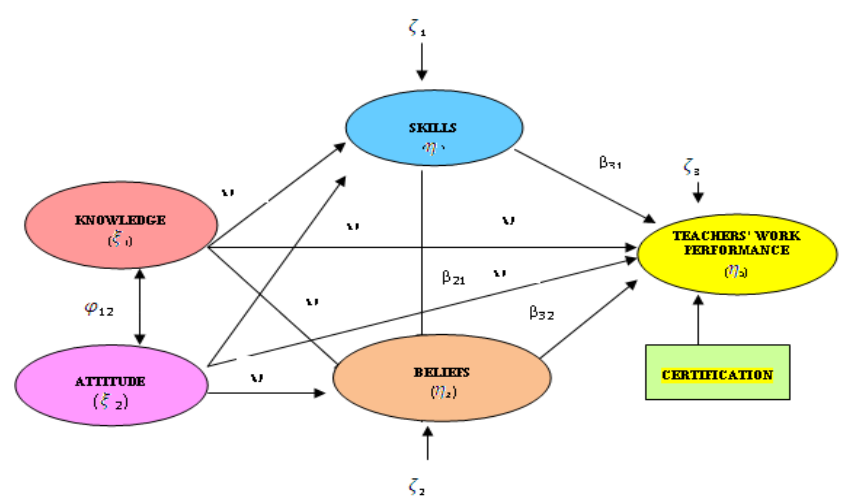

Figure 1

Mathematics Teachers' Work Performance Structural Model

Population and Study Sampling

The target population of this study comes from mathematics teachers in Yogyakarta, Indonesia as in the following table 1 below.

Table 1

The number of mathematics teachers

\begin{tabular}{lll}
\hline \multicolumn{1}{c}{ No } & District/ City & Number of mathematics teachers \\
\hline 1 & Bantul & 206 \\
2 & Sleman & 174 \\
3 & Gunung Kidul & 164 \\
4 & Kulon Progo & 119 \\
5 & Yogyakarta & 78 \\
Total & & 741 \\
\hline
\end{tabular}

The criterion of certified teachers is not an adopted strategy for sampling as during the sampling, the number of certified and those without certification were not known. But there are indications that most of the teachers are certified amounting to 85 percent. The distribution of mathematics teachers can be seen as follows in Table 2.

Table 2

Distribution of mathematics teachers

\begin{tabular}{|c|c|c|}
\hline No & District/ City & Number of mathematics teachers \\
\hline 1 & Bantul & 85 \\
\hline 2 & Sleman & 73 \\
\hline 3 & Gunung Kidul & 68 \\
\hline 4 & Kulon Progo & 48 \\
\hline 5 & Yogyakarta & 33 \\
\hline Total & & 306 \\
\hline
\end{tabular}

\section{FINDINGS}

After modifications by including the connection between the residual and the manifest, mathematics teachers' work performance structural model of direct examination results are as depicted in Figure 2. 


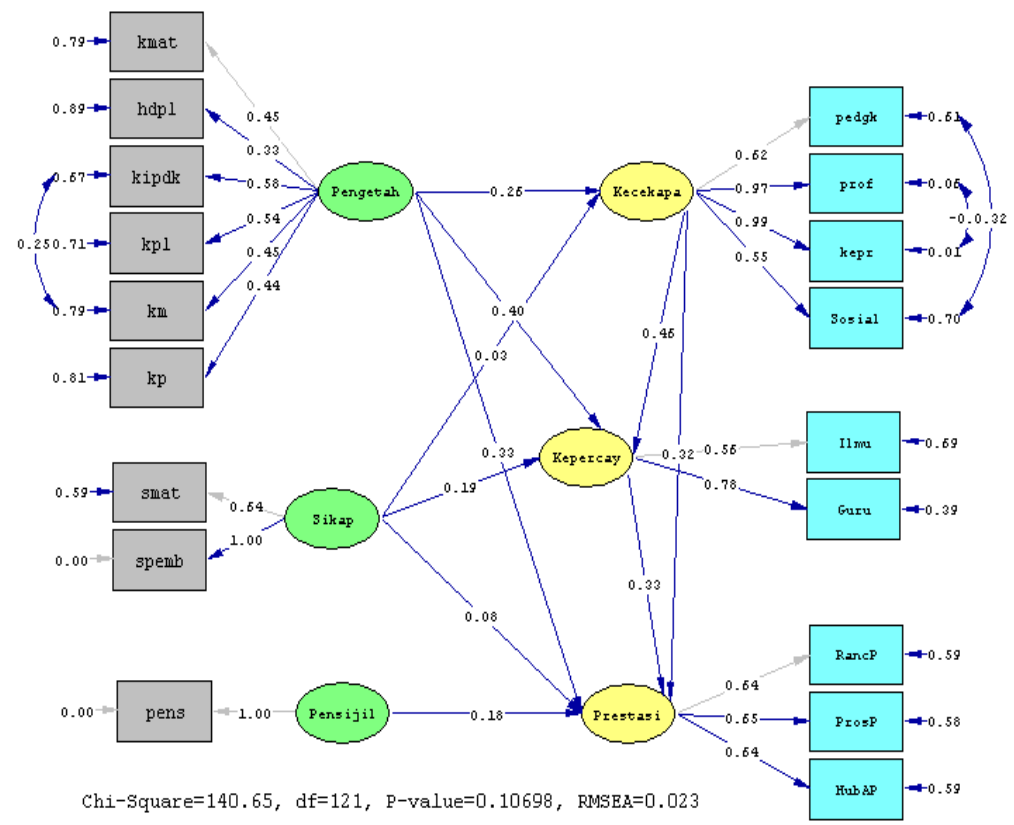

Figure 2

Test Result of Mathematics Teachers' Work Performance Structural Model

Exogen coefficient towards endogen is shown in table 5. Based on the results of the test, all exogen has direct positive and significant influence towards all endogen except attitude on mathematics teachers' work performance, which is not significant.

Table 3

Direct influence of exogen on endogen coefficient

\begin{tabular}{cclcccl}
\hline No & Endogen & Exogen & $\beta$ & $\gamma$ & $\mathrm{t}_{\text {val }}$ & Ket. \\
\hline \multirow{2}{*}{1} & \multirow{2}{*}{ Skills } & Knowledge & - & 0.2585 & 3.2718 & Sig \\
& & Attitude & - & 0.0316 & 0.6496 & Not Sig \\
\multirow{2}{*}{2} & \multirow{2}{*}{ Beliefs } & Knowledge & - & 0.4046 & 3.8511 & Sig \\
& & Attitude & - & 0.1890 & 3.0325 & Sig \\
& & Skills & 0.4565 & - & 5.9351 & Sig \\
& & Knowledge & - & 0.3271 & 3.0038 & Sig \\
3 & mathematics & Attitude & - & 0.0751 & 1.2537 & Not Sig \\
& teachers' work & Skills & 0.3233 & - & 4.1254 & Sig \\
& performance & Beliefs & 0.3327 & - & 2.5153 & Sig \\
& & Certification & - & 0.1847 & 3.4246 & Sig \\
\hline
\end{tabular}

\footnotetext{
$* \mathrm{t}_{\mathrm{table}}=1.968(\mathrm{df}=300, \propto=0.05)$
}

Mathematics teachers' work performance is explained in the model through three regressive functions. Functions 1 and 3 shows that attitude does not provide significant direct influence. (tval < 1.968) towards skills and mathematics teachers' work performance. However, attitude provides positive and significant direct influence (tval $\geq 1.968$ ) towards 
beliefs (function 2) and beliefs provide positive and significant direct influence towards mathematics teachers' work performance (function 3). It can be interpreted that attitude can provide positive and significant influence towards mathematics teachers' work performance by the growth of the teacher's beliefs. This fact does not support the hypothesis which states that attitude provides positive and significant influence towards mathematics teachers' work performance, but instead provides indirect positive and significant influence towards mathematics teachers' work performance through beliefs.

Knowledge, skills and beliefs of a teacher are important as prerequisites for teachers' work performance. The model shows that knowledge directly provides positive and significance influence towards skills (function 1) and teachers' work performance (function 3). Knowledge also provides indirect positive and significant influence on teachers' work performance through skills and beliefs (function 2). Test results show that all line coefficient: knowledge, skills and beliefs are represented by $t_{\text {val }} \geq 2$ which indicate significance. Therefore, all hypotheses which state the occurrence of direct or indirect positive and significant influence including knowledge, skills and beliefs towards mathematics teachers' work performance are accepted. In terms of differential test results, the certification is hypothesised to have the ability to enhance the quality of teachers which in turn, enhances work performance. Test results show that certified teachers' work performance obtained a higher average $(\bar{x}=81.4075)$ as compared to those without certification $(\bar{x}=73.9756)$. Both are significantly different with $\mathrm{t}_{\mathrm{val}}=2.778$ and $\mathrm{p}=0.006$. Therefore, certified mathematics teachers' work performance is better than that of those without certification. Hence, the hypothesis 4 of the study which states that certified mathematics teachers' work performance is better than that of those without certification is accepted.

\section{DISCUSSION}

\section{The Influence of Knowledge on Mathematics Teaching Performance}

Mathematical knowledge is a crucial factor for teachers' competency and ability to implement productive learning efficiently. Teachers' ability in learning is dissimilar to learning what is to be learnt. Knowledge is the source for the ability to create and utilise positive situations into learning to develop competency (Huda et al., 2016c). Teachers should be able to interpret and develop curriculum content used in a mutual education sequence, even with different social, economic and cultural backgrounds. Knowledge will demonstrate the quality of teachers in teaching as it is related to professionalism. Mathematics teachers should be equipped with knowledge on mathematics, mathematics with other subjects, education and curriculum, classroom management, teaching and education context. Teachers with an understanding of mathematical concepts will be able to improve teaching in class. Teachers' knowledge is an important component for the performance of teachers in a class (Agudelo-Valderrama, 2008). The knowledge needed by teachers is not only on the curriculum but goes beyond to co-curricular knowledge which enables them to develop it. Knowledge influences mathematics teachers' work performance in the sense that mathematics teachers' knowledge is part of being in the field, while mathematics teachers' work results can be seen from their achievement in skills, duty performance, work quality and teachers' responsibility (Van Maele \& Van Houtte, 2011). It refers to positive and significant influence of teachers' knowledge on mathematics teachers' work performance. 


\section{Influence of Attitude on Mathematics Teachers' Work Performance}

The attitude of teachers towards mathematics and the learning of mathematics may have chance to influence learning behaviour in the classroom. Teachers with negative attitude towards mathematics use learning methods based on rules, while those with positive attitude will adopt methods which are focused on understanding, exploration and finding links in mathematics. Teachers with a positive attitude towards mathematics would teach using methods of discussions, questioning and learner-centred methods, while those who are less positive are inclined to use teacher-centred methods (Huda et al., 2017b). Attitude, guidance and habit that serve as affective ability are important in the study of mathematics in the sense that attitude towards mathematics and the teaching of mathematics can influence teaching in a classroom (Di Martino \& Zan, 2015; Sonnert et al., 2015). Indirectly, the influence of attitude would be meaningful with the beliefs of teachers which can positively and significantly influence mathematics teachers' work performance by the nurturing of beliefs of the teacher.

\section{Influence of Skills on Mathematics Teachers' Work Performance}

Teachers' skills refer to the ability to implement teaching appropriately without stress, proactively and creatively by means of the best methods, so learning can be maximised. Pedagogical skills are helpful in teachers' expertise in mastering comprehensive mathematical knowledge in various disciplines and their applications. Professional skills assist teachers in planning systematic learning to achieve students' learning outcomes which are efficient and effective (Huda et al., 2017c). Personal skills are marked by strong, mature, stable, wise and authoritative character, woven with nobility that can be exemplified by students (Anshari et al., 2017; Huda et al., 2016c; Zan \& Di Martino, 2014). Social skills are the ability of the teacher to communicate effectively with students, among educators, the teaching force, parents of students and the community. With a positive and significant influence of skills towards mathematics teachers' work performance, it aims to enhance in producing better work output. As a result, pedagogic, professional, social and personal skills are the basis for teachers who contribute to their efforts (Savelsbergh et al., 2016; Huda et al., 2017d). Teaching mathematics effectively would lead to combine profound mathematical knowledge with the understanding of students and the use of a variety of pedagogical strategies. The findings also fortify the Indonesian regulation on education that teachers need skills to be professional educators in the sense that possess such skills with an ability to understand by improving skills. The findings of the study empirically also show that knowledge has a direct and significant influence on skills which may be interpreted that skills have the purpose of mediating the knowledge towards teachers' work performance.

\section{Influence of Beliefs on Mathematics Teachers' Work Performance}

Teaching beliefs include the beliefs on knowledge and mathematics education and belief in one's self as educators in the study of mathematics (Charalambous et al 2009). It refers to obtain knowledge in the mathematics discipline which covers internal and external factors with a direct positive and significant relationship of beliefs towards mathematics teachers' work performance. Similarly, knowledge and beliefs on teacher influence heavily on the practices and behaviour of a teacher in a classroom (Di Martino \& Zan, 2015). Without accurate mathematical beliefs, teachers will face difficulty in achieving success in teaching (Uyangor \& Ece, 2010; Huda et al., 2017e), where the need to implement mathematics 
learning in the sense which can engage into being confident of their mathematical knowledge with cooperation (Othman et al., 2016; Walshaw, 2012). The results from the mathematics teachers' work performance structural model in the summary of 5.1 shows that belief is an endogen from knowledge, attitude and skills. This empirically means that beliefs depend on the possessed knowledge, attitude and skills with pointing out that beliefs positively influence directly and significantly towards mathematics teachers' work performance.

\section{Influence of Certification on Mathematics Teachers' Work Performance}

The approach of a teacher in a practical class is determined by the concepts of teaching which he or she possesses. The choice of methods is not only on technicality of topics that will be delivered, but also by their perspective on learners and the way they are cultured. When teachers view students as empty vessels that grow mechanically, the teaching approach would take the banking system. On the other hand, if learners are viewed as God's potential creation that grows dynamically, the methods used are androgynous and dialogistic in nature. Professional teacher education assumes that the teaching force preparation models practised currently require revamping. Certification programmes and teachers' professional training is hoped to show steps of development in the roles of teaching as a profession. The certification, inclusive of portfolios, can be viewed to enhance mathematics teachers' work performance $(\mathrm{Xu}, 2004)$, with the criteria in evaluating teachers' work performance using certification and the use of portfolios (Fiedler, 2009; Huda et al., 2017f). This mathematics teachers' work performance structural model places certification as teachers' work performance. Findings show that teachers view certification as crucial in teachers' work performance. Other empirical findings show that generally, teachers' work performance among certified teachers are better than their counterparts without it and hence reveal the significance of certification. This would potentially expand an innovative approach on learning expertise (Huda et al., 2017j) in the sense that should be enhanced through examination process (Maseleno et al., 2017). Through cooperating with service learning (Huda et al., 2017k), the potential value of learning integration within autograph technology (Moksin et al., 2018) should be engaged with management process into social exposure in learning (Rosli et al., 2018) together with learning environment exposure (Huda et al., 2018c). As a result, the learning abilities with foundation (Huda and Sabani, 2018) may be complied with technology use for social exposure and learning process (Huda et al., 2019) in the sense which should gain the extent of competitive advantage (Huda et al., 2018d).

\section{CONCLUSION}

The finding of this study would be viewed from the theoretical and practical perspectives in which it theoretically supports the Indonesian government regulation in providing teaching services within educational system. The result revealed there are five core potentials in assisting the teaching performance. Those are knowledge, attitude, skills, beliefs of mathematics and certification. It can be reflected by the lesson planning construct, learning procedure and the connection between personalities in the sense that constructs the relation to other subjects, education and curriculum, and teaching and education. Towards pedagogical, professional, personal and social skills, this initiative refers to strengthen the beliefs construct among knowledge, education and self-confidence in assisting the teaching performance. As a result, formation, evaluation, and enhancement of teaching performance in mathematics play a significant role to enhance the quality of the teaching with comprehending the mathematics into the performance structural model. Moreover, the 
findings of this mathematics teaching performance based structural model would have the practical implications which become useful in observing such kind of work including attitude management in order to improve knowledge and skills. In particular, the finding on teachers' certification is that the certified mathematics teaching performance refers to support the rulers' requirement with possessing professionalism. Thus, the instrument used for each construct or indicator in this study also has practical implications for policy makers and researchers. It is related to the evaluation of mathematics teachers' work performance directly or indirectly.

\section{REFERENCES}

Agudelo-Valderrama, C. (2008). The power of Colombian mathematics teachers' conceptions of social/institutional factors of teaching. Educational Studies in Mathematics, 68(1), 37-54.

Aminin, S., Huda, M., Ninsiana, W., and Dacholfany, M.I. (2018). Sustaining civic-based moral values: Insights from language learning and literature. International Journal of Civil Engineering and Technology. 9(4), 157-174.

Anshari, M., Almunawar, M. N., Shahrill, M., Wicaksono, D. K., \& Huda, M. (2017). Smartphones usage in the classrooms: Learning aid or interference?. Education and Information Technologies, 22(6), 3063-3079.

Capraro, R. M., Capraro, M. M., Parker, D., Kulm, G., \& Raulerson, T. (2005). The mathematics content knowledge role in developing preservice teachers' pedagogical content knowledge. Journal of Research in Childhood Education, 20(2), 102-118.

Charalambous, C. Y., Panaoura, A., \& Philippou, G. (2009). Using the history of mathematics to induce changes in preservice teachers' beliefs and attitudes: Insights from evaluating a teacher education program. Educational Studies in Mathematics, 71(2), 161-180.

Koellner Clark, K., \& Lesh, R. (2003). A modeling approach to describe teacher knowledge. Beyond constructivism: Models and modeling perspectives on mathematics problem solving, learning, and teaching, 159-174.

Christensen, L. B. (2004). Experimental methodology. Allyn \& Bacon.

Di Martino, P., \& Zan, R. (2015). The construct of attitude in mathematics education. In From beliefs to dynamic affect systems in mathematics education (pp. 51-72). Springer International Publishing.

Ernest, P. (1989). The knowledge, beliefs and attitudes of the mathematics teacher: A model. Journal of Education for Teaching, 15(1), 13-33.

Fiedler, S., \& Pata, K. (2009). Distributed Learning Environments and Social Software: In search for a framework of design. In Dasgupta, S. (Eds.), Social Computing: Concepts, Methodologies, Tools, and Applications (pp. 145-158). Hershey, PA, USA: IGI Global.

Henderson, S., \& Rodrigues, S. (2008). Scottish student primary teachers' levels of mathematics competence and confidence for teaching mathematics: some implications for national qualifications and initial teacher education. Journal of education for Teaching, 34(2), 93-107.

Huda, M., Teh, K.S.M., Nor, N.H.M., and Nor, M.B.M. (2018a). Transmitting Leadership Based Civic Responsibility: Insights from Service Learning. International Journal of Ethics and Systems, 34(1), 20-31.

Huda, M., Maseleno, A., Muhamad, N.H.N., Jasmi, K.A., Ahmad, A., Mustari, M.I., Basiron, B. (2018b). Big Data Emerging Technology: Insights into Innovative Environment for Online Learning Resources. International Journal of Emerging Technologies in Learning 13(1), 23-36. 
Huda, M., Maseleno, A., Teh, K.S.M., Don, A.G., Basiron, B., Jasmi, K.A., Mustari, M.I., Nasir, B.M., and Ahmad, R. (2018c). Understanding Modern Learning Environment (MLE) in Big Data Era. International Journal of Emerging Technologies in Learning. 13(5), 71-85. doi: 10.3991/ijet.v13i05.8042

Huda., M. \& Sabani, N. (2018). Empowering Muslim Children's Spirituality in Malay Archipelago: Integration between National Philosophical Foundations and Tawakkul (Trust in God). International Journal of Children's Spirituality, 23(1), 81-94.

Huda, M. (2018). Empowering Application Strategy in the Technology Adoption: Insights from Professional and Ethical Engagement. Journal of Science and Technology Policy Management. doi.org/10.1108/JSTPM-09-2017-0044.

Huda, M., Hehsan, A., Basuki, S., Rismayadi, B., Jasmi, K. A., Basiron, B., \& Mustari, M. I. (2019). Empowering Technology Use to Promote Virtual Violence Prevention in Higher Education Context. In Intimacy and Developing Personal Relationships in the Virtual World (pp. 272-291). IGI Global.

Huda, M., Qodriah, S.L., Rismayadi, B., Hananto, A., Kardiyati, E.N., Ruskam, A., and Nasir, B.M. (2018d). Towards Cooperative with Competitive Alliance: Insights into Performance Value in Social Entrepreneurship in Creating Business Value and Competitive Advantage with Social Entrepreneurship. (pp.294). Hershey, PA: IGI Global.

Huda, M., Yusuf, J. B., Jasmi, K. A., \& Nasir, G. A. (2016a). Understanding Comprehensive Learning Requirements in the Light of al-Zarnūjī’s Ta'līm al-Muta'allim. Sage Open, 6(4), 1-14.

Huda, M., Yusuf, J. B., Jasmi, K. A., \& Zakaria, G. N. (2016b). Al-Zarnūjī's Concept of Knowledge ('ilm). SAGE Open, 6(3), 1-13.

Huda, M., Anshari, M., Almunawar, M. N., Shahrill, M., Tan, A., Jaidin, J. H., ... \& Masri, M. (2016c). Innovative Teaching in Higher Education: The Big Data Approach. The Turkish Online Journal of Educational Technology, 15(Special issue), 1210-1216.

Huda, M., Jasmi, K. A., Mohamed, A. K., Wan Embong, W. H., \& and Safar, J. (2016d). Philosophical Investigation of Al-Zarnuji's Ta'lim al-Muta'allim: Strengthening Ethical Engagement into Teaching and Learning. Social Science, 11(22), 5516-551.

Huda, M., Jasmi, K. A., Basiran, B., Mustari, M. I. B., \& Sabani, A. N. (2017a). Traditional Wisdom on Sustainable Learning: An Insightful View From Al-Zarnuji's Ta 'lim al-Muta 'allim. SAGE Open, 7(1), 1-8.

Huda, M., Shahrill, M., Maseleno, A., Jasmi, K. A., Mustari, I., \& and Basiron, B. (2017b). Exploring Adaptive Teaching Competencies in Big Data Era. International Journal of Emerging Technologies in Learning, 12(3), 68-83.

Huda, M., Jasmi, K. A., Hehsan, A., Shahrill, M., Mustari, M. I., Basiron, B., \& Gassama, S. K. (2017c). Empowering Children with Adaptive Technology Skills: Careful Engagement in the Digital Information Age. International Electronic Journal of Elementary Education, 9(3), 693-708.

Huda, M., Siregar, M., Ramlan, Rahman, S.K.A., Mat Teh, K.S., Said, H., Jamsari, E.A., Yacub, J., Dacholfany, M.I., \& Ninsiana, W. (2017d). From Live Interaction to Virtual Interaction: An Exposure on the Moral Engagement in the Digital Era. Journal of Theoretical and Applied Information Technology, 95(19), 4964-4972.

Huda, M., Sabani, N., Shahrill, M., Jasmi, K. A., Basiron, B., \& Mustari, M. I. (2017e). Empowering Learning Culture as Student Identity Construction in Higher Education. In A. Shahriar, \& G. Syed (Eds.), Student Culture and Identity in Higher Education (pp. 160-179). Hershey, PA: IGI Global. doi:10.4018/978-1-5225-2551-6.ch010 
Huda, M., Haron, Z., Ripin, M.N., Hehsan, A., and Yaacob, A.B.C. (2017f). Exploring Innovative Learning Environment (ILE): Big Data Era. International Journal of Applied Engineering Research, 12 (17), 6678-6685.

Huda, M., Maseleno, A., Jasmi, K.A., Mustari, M.I., and Basiron, B. (2017g). Strengthening Interaction from Direct to Virtual Basis: Insights from Ethical and Professional Empowerment. International Journal of Applied Engineering Research, 12 (17), 6901-6909.

Huda, M., Jasmi, K. A., Mustari, M. I., Basiron, B., Mohamed, A. K., Embong, W., ... \& Safar, J. (2017h). Innovative E-Therapy Service in Higher Education: Mobile Application Design. International Journal of Interactive Mobile Technologies, 11(4), 83-94.

Huda, M., Shahrill, M., Maseleno, A., Jasmi, K. A., Mustari, I., \& and Basiron, B. (2017i). Exploring Adaptive Teaching Competencies in Big Data Era. International Journal of Emerging Technologies in Learning, 12(3), 68-83.

Huda, M., Jasmi, K. A., Embong, W. H., Safar, J., Mohamad, A. M., Mohamed, A. K., Muhamad, N. H., Alas, Y., \& Rahman, S. K. (2017j). Nurturing Compassion-Based Empathy: Innovative Approach in Higher Education. In M. Badea, \& M. Suditu (Eds.), Violence Prevention and Safety Promotion in Higher Education Settings (pp. 154-173). Hershey, PA: IGI Global. doi:10.4018/978-1-5225-2960-6.ch009

Huda, M., Jasmi, K. A., Alas, Y., Qodriah, S. L., Dacholfany, M. I., \& Jamsari, E. A. (2017k). Empowering Civic Responsibility: Insights From Service Learning. In S. Burton (Ed.), Engaged Scholarship and Civic Responsibility in Higher Education (pp. 144-165). Hershey, PA: IGI Global. doi:10.4018/978-1-5225-3649-9.ch007

Huntly, H. (2008). Teachers' work: Beginning teachers' conceptions of competence. The Australian Educational Researcher, 35(1), 125-145.

Isaac, S., \& Michael, W. B. (1971). Handbook in research and evaluation. San Diego: Edits Publisher

Klassen, R. M., \& Tze, V. M. (2014). Teachers' self-efficacy, personality, and teaching effectiveness: A meta-analysis. Educational Research Review, 12, 59-76.

Maseleno, A., Huda, M., Siregar, M., Ahmad, R., Hehsan, A., Haron, Z., Ripin, M.N., Ihwani, S.S., and Jasmi, K.A. (2017). Combining the Previous Measure of Evidence to Educational Entrance Examination. Journal of Artificial Intelligence 10(3), 85-90.

Maseleno, A., Pardimin, Huda, M., Ramlan, Hehsan, A., Yusof, Y.M., Haron, Z., Ripin, M.N., Nor, N.H.M., and Junaidi, J. (2018a). Mathematical Theory of Evidence to Subject Expertise Diagnostic. ICIC Express Letters, 12 (4).

Maseleno, A., Huda, M., Jasmi, K.A., Basiron, B., Mustari, I., Don, A.G., and Ahmad, R. (2018b). Hau-Kashyap approach for student's level of expertise. Egyptian Informatics Journal, doi.org/10.1016/j.eij.2018.04.001.

Ministry of Education (2011). Survei Internasional TIMSS. Trends in International Mathematics and Science Study (TIMSS).

Ministry of Education. (2005). Undang-Undang Republik Indonesia Nomor 14 Tahun 2005 tentang Guru dan Dosen.

Moksin, A. I., Shahrill, M., Anshari, M., Huda, M., \& Tengah, K. A. (2018). The Learning of Integration in Calculus Using the Autograph Technology. Advanced Science Letters, 24(1), 550-552.

Munck, M. (2007). Science pedagogy, teacher attitudes, and student success. Journal of Elementary Science Education, 19(2), 13-24. 
Lim-Teo, S. K., Low, E. L., Wong, A. F., \& Chong, S. (2008). Motivation, competence, and confidence to teach-an exploratory study of the impact of an initial teacher preparation (ITP) programme on beginning primary school teachers. KEDI Journal of Educational Policy, 5(2), 41-61.

Van Maele, D., \& Van Houtte, M. (2011). The quality of school life: Teacher-student trust relationships and the organizational school context. Social Indicators Research, 100(1), 85-100.

Othman, R., Shahrill, M., Mundia, L., Tan, A., \& Huda, M. (2016). Investigating the Relationship Between the Student's Ability and Learning Preferences: Evidence from Year 7 Mathematics Students. The New Educational Review, 44(2), 125-138.

Riaz, M. N. (2000). Student Evaluation of the University Teaching Quality: Analysis of a teacher's rating scale for a sample of University students. Pakistan Journal of psychological Research, 15, 107-117.

Rosli, M.R.B., Salamon, H.B., and Huda, M. (2018). Distribution Management of Zakat Fund: Recommended Proposal for Asnaf Riqab in Malaysia. International Journal of Civil Engineering and Technology 9(3), pp. 56-64.

Savelsbergh, E. R., Prins, G. T., Rietbergen, C., Fechner, S., Vaessen, B. E., Draijer, J. M., \& Bakker, A. (2016). Effects of innovative science and mathematics teaching on student attitudes and achievement: A meta-analytic study. Educational Research Review, 19, 158-172.

Shulman, L. (1987). Knowledge and teaching: Foundations of the new reform. Harvard Educational Review, 57(1), 1-22.

Shulman, L. S. (1986). Those who understand: Knowledge growth in teaching. Educational Researcher, 15(2), 4-14.

Sonnert, G., Sadler, P. M., Sadler, S. M., \& Bressoud, D. M. (2015). The impact of instructor pedagogy on college calculus students' attitude toward mathematics. International Journal of Mathematical Education in Science and Technology, 46(3), 370-387.

Suffian, H.B. \& AbdulRahman, S. B. (2010). Teacher's Choice and Use of Examples in The Teaching and Learning of Mathematics in Primary School and Their Relations to Teacher's Pedagogical Content Knowledge (PCK). Procedia-Social and Behavioral Sciences, 8, 312-316.

Toh, K. A., Ho, B. T., Chew, C. M., \& Riley, J. P. (2003). Teaching, teacher knowledge and constructivism. Educational Research for Policy and Practice, 2(3), 195-204.

Uyangor, S. M., \& Ece, D. K. (2010). The Attitudes of the Prospective Mathematics Teachers towards Instructional Technologies and Material Development Course. Turkish Online Journal of Educational Technology-TOJET, 9(1), 213-220.

Walshaw, M. (2012). Teacher knowledge as fundamental to effective teaching practice. Journal of Mathematics Teacher Education, 15(3), 181-185.

Wilkins, J. L. (2008). The relationship among elementary teachers' content knowledge, attitudes, beliefs, and practices. Journal of Mathematics Teacher Education, 11(2), 139-164.

$\mathrm{Xu}, \mathrm{Y}$. (2004). Teacher portfolios: An effective way to assess teacher performance and enhance learning. Childhood Education, 80(4), 198-201.

Zulkardi, Z. (2002). Developing a learning environment on realistic mathematics education for Indonesian student teachers. Doctoral Dissertation. University of Twente.

Zan, R., \& Di Martino, P. (2014). Students' attitude in mathematics education. In Encyclopedia of mathematics education (pp. 572-577). Springer Netherlands. 